\title{
SIGNS AND SYMBOLS IN TRADITIONAL BUBAK KAWAH IN JOMBANG DISTRICT
}

\author{
Muhibatul Imamah, Rusli Ilham Fadli ${ }^{2}$ \\ ${ }^{1,2}$ Pendidikan Bahasa dan Sastra Indonesia, Fakultas Ilmu Pendidikan, Universitas Hasyim Asy'ari
}

Corresponding Author: ${ }^{1}$ muhibatulimama1234@gmail.com

\begin{abstract}
This study aims to determine the relationship between signs and symbols in the traditional Bubak crater using the semiotic theory. This type of research is qualitative using the semiotic theory. There are 18 semiotic aspects in this study. Data collection techniques used observation, interviews and translites. The data analysis procedure was carried out by reading the data, selecting the data and entering the data into the initial analysis table. Based on the results of the research, it shows that the ritual order in the Bubak Kawah traditional procession in Gudo District, Jombang Regency, has 8 signs which are obtained in each sequence of the Bubak Kawah traditional procession. While the ubo rampe or equipment in the Bubak Kawah Traditional Procession in Gudo District, Jombang Regency has 10 symbols, which symbols are obtained on the equipment set at the Bubak Kawah traditional procession. Furthermore, there will be the meaning of each sign and symbol obtained at the Bubak Kawah traditional procession.
\end{abstract}

Keywords: Signs, Symbols, Bubak Kawah

\section{TANDA DAN SIMBOL DALAM ADAT BUBAK KAWAH DI KABUPATEN JOMBANG}

\begin{abstract}
Abstrak
Penelitian ini bertujuan untuk mengetahui hubungan tanda dan simbol dalam Adat Bubak kawah yang menggunakan teori Semiotik. Jenis penelitian ini adalah kualitatif dengan menggunakan teori Semiotik. Aspek Semiotik dalam penelitian ini bejumlah 18. Teknik pengumpulan data menggunakan observasi, wawancara dan translite. Prosedur penganalisisan data dilakukan melalui pembacaan data, menyeleksi data dan dan memasukkan data pada tabel analisis awal. Berdasarkan hasil dari penelitian menumjukkan bahwa tata ritual dalam prosesi adat Bubak Kawah di Kecamtan Gudo Kabupaten Jombang ini terdapat 8 tanda yang mana tanda itu di dapat pada setiap urut-urutan prosesi adat Bubak Kawah berlangsung. Sedangkan ubo rampe atau perlengkapan yang ada dalam Prosesi Adat Bubak Kawah di Kecamatan Gudo Kabupaten Jombang ini memiliki 10 simbol yang mana simbol didapat pada setian perlengkapan yang ada pada acara prosesi adat Bubak Kawah. Selanjutnya akan terdapat makna pada setiap tanda dan simbol yang di dapat pada acara prosesi aadat Bubak Kawah.
\end{abstract}

Kata Kunci: Tanda, Simbol, Adat, Bubak Kawah

\section{PENDAHULUAN}

Bahasa juga merupakan sebagai

tatanan semiotik. Diketahui presensi bahasa selaku sistem yang bersifat bidimensional. Dalam pengunaan bahasa memiliki sistem tersendiri dan bersangkutan dengan sistem yang lainnya (Aminunddin, 2015: 36). Ferdinand de Saussure berpendapata bahwa adapun bahasa ialah sistem tanda yang tidak dapat terpisahkan dengan pemakainnya, aspek simbol dan semantik (Aminuddin, 2015: 38). Bahasa sebagai sistem semiotik menyimpulkan bahwa pengunaan bahasa 
Jurnal DISASTRI (Pendidikan Bahasa dan Sastra Indonesia)

Volume 3, Nomor 1, April 2021| P-ISSN : 2716-4114 | E-ISSN: 2722-3329

dalam komunikasi diawali dan diikuti beberapa unsur, mencakup budaya dan sistem sosial dalam suatu masyarakat budaya, sistem kebahasaan yang mendasari bentuk kebahasaan yang dipakai dan aspek semantik yang dikandungnya.

Menurut Chaer (2012: 44) bahasa merupakan sistem lambang yang berbunyi. Bahwa yang dilambangkan adalah suatu konsep, suatu ide, suatu pengertian, atau fikiran, maka bisa dikatakan bahwa bahasa itu memiliki makna. Adapun bahasa merupakan suatu sistem tanda dan simbol yang memiliki makna. Dalam upacara adat Bubak kawah ini memiliki beberapa prosesiprosesi yang dilalui.

Upacara Bubak Kawah membutuhkan perlengkapan laksana penunjang jalannya upacara. Upacara merupkan salah satu hasil pelukisan simbol-simbol yang memusat pada sesuatua yang amat baik, sehingga dengan perlengkapan-perlengkapan yang dipergunakan dalam prosesi menjadi do'a yang akan dikongkretsasikan dalam kehidupan nyata oleh kedua pengantin. Perlengkapan adalah pokok dasar upacara pernikahan adat Jawa. Hal ini mampu dipelajari secara semiotik, terkemuka istilah-istilah upacara Bubak Kawah di Kecamata Gudo Kabupaten Jombang. Tujuan kegiatan ini adalah mengenal suatu penglihatan hidup dari faktor penduduk asli. Presepsi kebudayaan ditunjukkan dalam perbuatan yang disangkutkan dengan berbagai kelompok masyarakat tertentu, seperti cara hidup atau adat masyarakat.
Adat-istiadat yakni suatu kenormaan yang komplit oleh penganutnyan dianggap berarti dalam hidup bersama dimasyarakat. Adat-istiadat tersebut bermanfaat menjadi pedoman perbuatannya, dan pedomann untuk mengendalikan setiap tingkah laku manusia. Dalam pelaksanaan upacara adat bahasapun tidak bisa ditinggalkan. Seperti halnya simbol dan tanda yang digunakan dalam upacara tersebut yang memiliki makna-makna tersendiri.

Prosesi secara adat Bubak Kawah ini tidak banyak masyarakat Jombang yang mengetahui hanya beberapa daerah saja yang masih tetap melestarikan adat ini. Masyarakat Jombang pun masih banyak yang tidak mengetahui tanda, simbol dan makna apa yang terkandung dalam upacara adat Bubak Kawah. Misalnya pada prosesi pembukaan isi kendil yang mana kendil itu disediakan dua yang satu berada didepan sang punya hajat laki-laki dan yang satunya berada didepan sang punya hajat perempuan. Dua kendil tersebut mempunyai nama yang pertama kendil Lumboho Denok dan Nyai Tani. Bukan hanya kendil terdapat pula kendi (tempat minum orang Jawa) dan juga banyak makanan yang tersediakan didepan sang empun hajat mantu pertama pada anak perempuannya. Dalam prosesi ini banyak masyarakat yang belum seluruhnya mengetahui tanda dan simbol yang memiliki makna dalam istilah Kendil Lumboho Denok dan Nyai Tani, Kendi Pertuyo dan makanan-makanan yang mempunyai makna tersendiri. Maka 
Jurnal DISASTRI (Pendidikan Bahasa dan Sastra Indonesia)

Volume 3, Nomor 1, April 2021| P-ISSN : 2716-4114 | E-ISSN: 2722-3329

penelitian ini difokuskan pada tanda dan simbol yang bermakna yang terdapat dalam prosesi upacara adat Bubak Kawah. Berdasarkan penjelasan sebelumnya, telah dipaparkan bahwa upacara adat Bubak Kawah memiliki tanda dan simbol yang memiliki makna dalam setiap prosesinya. Penelitian ini akan menganalisis simbol, tanda dan makna dalam kirab adat tersebut dengan menerapkan kajian Semiotik.

\section{LANDASAN TEORI}

Semiotik ialah suatu kajian ilmu atau kaidah analisis untuk mengaji tanda. Menurut Lechte semiotik adalah teori berkenaan tanda atau penandaan. Berlandaskan taksiran tersebut mampu menyimpulkan bahwa semiotik adalah suatu bidang ilmu yang menyelidiki semua bentuk tanda dan penandaan (Sobur, 2016: 15). Menurut Ferdinand de Saussure semiotik selaku ilmu yang mempelajari tentang tanda sebagaian pada kehidupan sosial (Sopianah, 2013: 28). Semiotik berawal dari bahasa Yunani 'semion' yang berarti 'tanda'atau 'seme' yang bermakna 'penafsiran tanda'. Menurut Kurniawan semiotik berasal dari studi unggul dan skolastik atas seni nalar, retoroika dan poetika, 'Tanda' pada waktu tedahulu masih menunjukkan makna pada adanya hal lain seperti contoh, muncul asap karena adanya api (Sobur, 2016: 17).

Jika tanda digunakan pada tandatanda bahasa, kata kalimat, makna huruf, tidak mempunyai arti pada dirinya sendiri. Tanda sendiri semata-mata berarti (significant) yang berkaitan oleh pembacanya. Pembacalah yang mampu mengabungkan tanda dengan yang ditandakan (signifie) cocok dengan formalitas pada sistem bahasa yang berhubungan. Pada saat penelitian sastra, sering diperhatikan ikatan sintaksis dengan tanda-tanda (stuktualisme) dan kaitan antara tanda dengan yang ditandakan (Semantikan) (Sobur, 2016: 17).

Menurut Paul Cobley dan Litza Jansz, keberadaan studi penandaan mewujudkan fenomena modern. Tanda dalam pamikiran Piece, yakni suatu yang hadir dan dihadirkan (cultivated). Ia ada dalam proses eksplanasisi yang mengalir (Sobur, 2016: 17). Menurut Doede Nauta memilah tiga tingkat berpangkutan semiotik, yaitu padanan sintaksis (syntactic level), padanan semantik, (semantic level) dan padanan pramatik (pragmatic level). Selain ketiga perbedaan tersebut Doede Nauta juga menyampaikan tiga mecam inkuiri semiotika, yakni semiotik murni (pure), Deskriptif (descriptive) dan terapan (applied) (Sobur, 2016: 19).

Semiotik tersusun dari tiga poros yaitu, poros horizontal yang menyuguhkan tiga jenis penyelidikan semiotik (murni, deskriptif dan terepan). Poros kedua poros vertikal yang menyediakan tiga taratan ikatan semiotik (sintaktuk, semantik dan pragmatik) dan poros yang terakhir adalah poros yang menyediakan tiga kategori 
sarana informasi (signals, signs dan symbols)

(Sobur, 2016: 19).

a) Tanda

Tanda merupakan kajian semiotik yang paling inti bisa di lihat dari pemaparan semiotik di atas yang menjelaskan semiotik adalah ilmu tentang tanda. Tanda ialah suatu yang terbentuk dari suatu yang lain atau memperbanyak perspektif yang berlainan pada susuatu, dengan mengunakan apapun dengan mengartikan sesuatu hal lainnya (Berger, 2015: 1). Menurut ittlejohn tanda-teada (signs) ialah dasar dari semua komunikasi (Sobur, 2016: 15). Dari pandangan Littlejohn tanda-tanda merupakan perantara dalam melantaskan komunikasi bersama sesamanya.

Menurut Ferdinand de Saussure mengemukakan tanda secara kesatuan yang tidak mampu terpisahkan dari dua bidang, yakni bidang pola suara (sound pattern) merupakan gambaran suara yang diproduksi didalam otak. Bidang kedua adalah konsep yaitu berupa makna dan kesan yang bersifat abstrak. Dari kedua bidang ini menegaskan bahwa antara bentuk dan makna adalah sebuah kesatuan yang tidak dapat dipisahkan (Piliang, 2012: 249-250).

Struktur tanda yang tetap, stabil yang tidak berubah ini kemudian dikembangkan oleh Roland Barrthes menjadi penanda (signifier) atau wujud,

ekspresi dan bidang petanda (signified), atau rancangan makna yang membentuk seluruh tanda (Piliang, 2012: 249-250). Semiotik strukturalisme memandang tanda merupakan struktur yang mengikat.

Saussure mengambarkan tanda laksana struktur biner, yakni truktur yang terdiri dri dua bagian yaitu (1) bagian fisik, yang disebut penanda dan (2) bagian konseptual, yang disebut patanda. Dari segi relasi $X=Y$ penanda sama dengan $X$ dan petanda sama dengan $Y$ :

\[ =Y \]
$X=$ penanda
(=bagian fisik) $Y=$ petanda
(=bagian konseptual)
Saussure mengibaratkan tautan
antara penanda dan petanda, X=Y,
bersifat bebas dan terbangun setelah
lama suatu tujuan sosial tertentu
(Danesi, 2011: 30).
Simbol $\quad$ Menurut Susanne K. Langer
menyatakan bahwa kepentingan dasar
yang ada dalam diri manusia merupakan
kepentingan akan simbolis. Kegunaan
penyusunan simbol pada manusia
adalah kepentingan dasar seperti
makan, melihat dan bergerak. Ini
merupakan proses fundamental yang
berlangsung setiap hari (Sobur, 2016:
154). Simbol hadir pada suatu konteks
yang bermacam dalam berbagai


kepentingan. Menurut Wellek \& Werren

simbol ialah suatu sebutan pada suatu logika semantik, matematika, semiotik dan epistemologi (Sobur, 2016: 154).

Menurut Ferdinand de Saussure simbol adalah jenis tanda yang berhubungan dengan petanda dan penanda yang selah-olah bersifat arbiter. Saussure menjelaskan seperti berikut:

'salah satu karakterlistik dari simbol ialah simbol tidak pernah benarbenar arbiter. Hal ini bukannya tanpa alasan karena ada ketidak sempurnaan ikatan alamiah antara penanda dan pertanda. Simbol keadilan yang berupa satu timbangan taidak dapat digantikan oleh simbol lainnya seperti kendaraaan (kereta) misalnya (Berger, 2015: 27)'.

Dari kutipan penjelas diatas dapat disimpulkan bahwa simbol tidak benar-benar bersifat arbitrer. Ketidaksempurnaan dalam hubungan alamiah sela penanda dan petanda. Simbol sebagi keseimbangan yang berupa ukuran yang tidak bisa sembarangan dirubah dengan simbol lainnya seperti kendaraan (kereta).

Saussure menggambarkan seorang dewi pada saat mata tertutup sedang memegang timbangan itu bakan lebih menguuatkan simbol akan keadilan, karena mempererat makna ketidak berpihakkan dan kesepadanan memperbuat yang kita asosiasikan dengan kebijaksanaan. Gambaran ini menjadi konvesional keadilan pada pendapat dunia Yahudi-Kriten Barat (Berger, 2015: 27-28).

Menurut Hartoko \& Rahmanto simbol secara etimologi simbol (symbol) berawaal dari bahasa Yuneni 'symballiem' yang berarti melontarkan bersama sesuatu (benda, perbuatan) yang dikaitkan pada suatu ide. Sedangkan menurut Herusatato simbol berawal dari kata 'symbolos' yang berarti tanda atau ciri yang memberitahu suatu hal kepada seseorang. Adapun menurut Sobur simbol ialah wujud yang menandai suatu yang lain di luar perwujudan simbolik itu sendiri. Ikatan anatara simbol sebagai penanda pada suatu yang ditandakan (petaanda) bersifat konvesional. Berdasarkan konvensi itu para pemakaianya mengartikan ciri hubangan antera simbol pada objek yang diacu dan mengartikan maknanya (Sobur, 2016: 155-156).

Menurut Moeliono (Basir, 2010: 103) istilah simbol sendiri berarti lambang, yaitu bentuk pernyataan bahasa untuk mengekspresikan ide-ide yang mengungkapkan dalam sistem tanda atau lambang tertentu. Maka Moeliono memaparkan bahwa bahasa simbol yakni merupakan sistem tenda atau lambang yang dihasilkan oleh sekerumun orang atau budaya spesifik 
dengan tujuan den maksud yeng telah disetujui bersama oleh komunitasnya.

Menurut Sobur (2016: 156) simbol tidak boleh disikapi secara isolative, terlepas dengan asosiatifnya dangan mengunakan simbol yang lainnya. Simbol berlain dengan bunyi. Simbol mempunyai kesatuan bentuk dan makna. Simbol berlain pula dengan makna (sign), simbol yakni kata atau sesuatu yang bisa dianalogikan sebagai kata yang sudah bersangkutan dengan pengartian pemakaian, kaidah pemakaian dan kreasi pemberian makna simbol ini disebut sebagai simbolik. Simbol-siimbol membantu mempertautkan tingkah laku dan prestasi kebudayaan (Berger, 2015:28).

c) Makna

Menurut Ferdinand de Saussure (Chaer, 2012: 29) disetiap tanda linguistik terdapat dari dua unsure, yakni (1) yang diartikan (Prancis: Signifie' Inggris: Signified) dan (2) Yang mengartikan (Prancis: signifiant, Inggris: Signifiar) yang diartikan itu sebaiknya tidak lain dari konsep atau makna dari sesuatu tanda bunyi. Selain itu yang mengartikan itu adalah tidak lain dari beberapa bunyi itu, yang terbuat dari beberapa fonem bahasa yang berkaitan, maka, dengan kata lain setiap tandaliinguistik terdapat dari unsure bunyi dan unsur makna. Kedua unsure ini adalah unsure pada bahasa (intralingual) yang biasa mengacu/ merajuk kepada suatu relefen yang membentuk unsure luar bahasa (ekstralingual).

Tanda linguistik yang dieja $<$ meja $>$. Tanda ini terdapat dari unsure makna atau yang dimaknakan 'meja' dan unsure bunyi atau yang memaknakan dalam wujud deretan funem [m, e, j, a] kemudian tanda $<$ meja $>$, yang dalam arti terdapat dari unsure makna dan unsure bunyinya mengacu pada suatu referen yang ada diluar bahasa, yakni sebuah meja, sebagai salah satu benda dalam rumah tanga. Kalau kata <meja> adalah sebagai hal yang menandai (tandalinguistik), maka sebuah <meja > sebagai benda ini adalah hal yang di beri tanda.

Namun pada bidang linguistik istilah yang biasa dipakai untuk tanda linguistik itu adalak leksem. Sebuah leksem atau kata. Dengan demikian, menerut teori yang diluaskan Ferdinand de Saussure bahwa makna ialah "Pengertian" atau "konsep" yang dipunyai atau terdapat pada sebuah tanda-linguistik. Jiika tanda linguistik itu dibatakan identitasnya dengan kata atau leksem, maka makna ialah penjelasan atau konsep yang dipunyai oleh setiap kata atau leksem (Chaer, 2012: 287).

\section{METODE PENELITIAN}

Penelitian ini menggunakan pendekatan kualitatif. Pendekatan kualitatif digunakan karena sumber data yang dikaji peneliti adalah prosesi Adat 
Bubak Kawah. Oleh karena itu peneliti menggunakan pendekatan kualitatif sebab dalam penelitia ini tidak berupa angkaangka melainkan berupa kata dan kalimat. Data yang dipakai pada penelitian ini berupa data yang berasal dari rekaman vidio dan transkip data yang telah dilakukan. Data tersebut berupa prosesiprosesi atau setiap tahapan yang terdapat dalam Adat Bubak Kawah yang mengandung tanda, simbol dan maknanya. Data yang digunakanpun hanya data yang memuat tanda, simbol, dan makna tidak keseluruhan agar pembahasan tidak keluar dari yang diteliti. Teknik pengumpulan data penelitian ini berupa metode dokumentatif. Metode dokumentatif menjadi metode yang digunakan untuk mendekumentasikan prosesi-prosesi Adat Bubak Kawah yang berupa rekaman vidio, transkip data dan wawancara. Teknik yang dipakai pada penelitian ini ialah dengan teori analisis semiotik. Teknik ini dilakukan dengan menganalisis suatu data yang berupa prosesi-prosesi adat dari segi tanda, simbil dan maknanya pada setiap prosesi Adat Bubak Kawah.

\section{PEMBAHASAN}

Berdasarkan hasil penelitian yang telah dilakukan, pada pembahasan ini akan menguraikan tentang aspek semiotik yang terdapat pada Adat Bubak Kawah di Kecamatan Gudo Kabupaten Jombang secara terperinci mengenai tanda, simbol dan makna yang terkandung pada adat tersebut. Penelitian untuk meneliti suatu objek dengan menggunakan semiotikan bukanlah pertama kali dilakukan. Penelitian yang terdahulu yang relevan sudah ada yang meneliti suatu objek menggunakan teori semiotik seperti yang dilakukan oleh Afifatur Rohmah Al-Faruq pada tahun 2018 yang berjudul "Aspek Semiotik Adat Begawi Cakak Pepadun Di Kabupaten Lampung Tengah" Penelitian ini sama menggunakan kajian semiotik. Akan tetapi, penelitian ini meneliti mengenai makna yang terdapat dalam upacara adat penikahan, makna prosesi, tanda dan simbol yang terdapat dalam upacara adat pernikahan. Penelitian ini menjelaskan makna berjalannya acara Begawai Cakak Pepadun, tanda yang terdapat disetiap prosesi dan juga simbol konteks yang ada pada upacara adat tersebut. Hal ini dimaksud supaya hasil penelitian menjadi pembahasan yang bisa diterima.

\section{a) Keeratan Hubungan antara Tanda dan Simbol}

Menurut Ferdinand de Saussure mengemukakan tanda secara kesatuan yang tidak mampu terpisahkan dari dua bidang, yakni bidang pola suara (sound pattern) merupakan gambaran suara yang diproduksi didalam otak. Bidang kedua adalah konsep yaitu berupa makna dan kesan yang bersifat abstrak. Dari kedua bidang ini menegaskan bahwa antara bentuk dan makna adalah sebuah kesatuan yang tidak dapat dipisahkan (Piliang, 2012: 249-250). 
Saussure mengambarkan tanda laksana struktur biner, yakni truktur yang terdiri dri dua bagian yaitu (1) bagian fisik, yang disebut penanda dan (2) bagian konseptual, yang disebut patanda (Danesi, 2011: 30).

Penanda dan petanda merupakan dua unsur yang tidak dapat terpisahkan. Penanda merupakan unsur fisik (pola suara atau bunyi) sedangkan penanda merupakan konsep yang dihasilkan oleh bunyi yang muncul (penanda). Seperti halnya tanda yang terdapat pada Adat Bubak Kawah di Kecamatan Gudo Kabupaten Jombang. Penanda yang ada pada adat tersebut memunculkan petanda atau sebuah konsep dari penanda yang menjadi tanda. Tanda berhubungan erat dengan simbol karena hampir pada setiap tanda memunculkan simbol seperti contoh tanda pada prosesi memakan pisang, memakan pisang merupakan pisang yang akan dimakan ini bernama pisang raja dan di ambil dari dalam kendil. Cara memakan pisang ini yakni Bapak dan Ibu yang mempunyai hajat agar saling menyuapkan bukan untuk di makan sendiri-sendiri. Buah pisang raja yang dimakan tersebut memunculkan simbol kemanisan atau kebaikan pada buah yang dimakan oleh Bapak dan Ibu yang mempuyai hajat. Dalam contoh tersebut menjelaskan bahwa adanya tanda bisa memunculkan simbol dikarenakan satu tanda sudah bisa memuncukan simbol untuk keseluruhan. Seperti dalam prosesi adat Bubak Kawah seperti dalam prosesi penyebutan benda dan artinya. Ada suroh dalam prosesi penyebutan benda menjadi simbol bertemu, enjet menjadi simbol perwujudan, kemudian ada bakoh yang memiliki simbol kesepakatan bersama. Namun dengan demikian simbol lebih mendominasi dari pada tanda pada prosesi Adat Bubak Kawah.

Tabel 4.1

\begin{tabular}{|c|c|c|}
\hline No & $\begin{array}{c}\text { Aspek } \\
\text { Semiotik }\end{array}$ & Jumlah \\
\hline 1. & Tanda & 8 \\
\hline 2. & Simbol & 10 \\
\hline \multicolumn{2}{|c|}{ Jumlah } & 18 \\
\hline
\end{tabular}

\section{b) Simbol tidak selalu Bersifat Arbiter}

Menurut Ferdinand de Saussure simbol adalah jenis tanda yang berhubungan dengan petanda dan penanda yang selah-olah bersifat arbiter. Saussure menjelaskan seperti berikut:

'salah satu karakterlistik dari simbol ialah simbol tidak pernah benar-benar arbiter. Hal ini 
bukannya tanpa alasan karena ada ketidak sempurnaan ikatan alamiah antara penanda dan pertanda. Simbol keadilan yang berupa satu timbangan taidak dapat digantikan oleh simbol lainnya seperti kendaraaan (kereta) misalnya (Berger, 2015: 27)'.

Dari kutipan penjelasan diatas dapat disimpulkan bahwa simbol tidak selalu bersifat arbiter karena simbol bersifat konvesional dengan adanya kesepakatan dari satu kelompok untuk meyakini sebuah simbol seperti contoh kebaikan yang berupa buah pisang raja tidak bisa sembarangan di rubah dengan simbol buah pisang lainnya. Saussure menggambarkan seorang dewi pada saat mata tertutup sedang memegang timbangan itu bakan lebih menguuatkan simbol akan keadilan, karena mempererat makna ketidak berpihakkan dan kesepadanan memperbuat yang kita asosiasikan dengan kebijaksanaan. Gambaran ini menjadi konvesional keadilan pada pendapat dunia Yahudi-Kriten Barat (Berger, 2015: 27-28).

\section{c) Peran Konteks dalam Penentuan} Makna

Menurut Ferdinand de Saussure bahwa makna ialah "Pengertian" atau "konsep" yang dipunyai atau terdapat pada sebuah tanda-linguistik. Jiika tanda linguistik itu dibatakan identitasnya dengan kata atau leksem, maka makna ialah penjelasan atau konsep yang dipunyai oleh setiap kata atau leksem (Chaer, 2012: 287). Makna, tanda dan simbol saling berhubungan. Dalam mengidentifikasi makna pada tanda tidak bisa secara langsung mengidentifikasikannya. Akan tetapi harus melihat konteks pada tanda tersebut, dikarenakan untuk menentukan makna pada tanda harus melihat konteks yang telah disepakati karena makna itu sendiri bersifat konvesional. Tanda akan memiliki makna yang berbeda jika berada dalam konteks yang berbeda. Seperti halnya pada tanda linguistik yang dieja $<$ meja $>$. Tanda ini terdiri dari unsur makna atau yang diartikan 'meja' dan dan unsur bunyi atau yang mengartikan dalam wujud runtunan fonem $[\mathrm{m}, \mathrm{e}, \mathrm{j}, \mathrm{a}]$. Lalu tanda <meja $>$, yang dalam arti terdiri dari unsur makna dan unsur bunyinya mengacu kepada suatu referen yang berada diluar bahasa, yaitu sebuah meja, sebagai salah satu perabot rumah tangga. Tanda yang mengacu pada suatu referensi dari luar bahasa ini merupakan konteks (Chaer, 2013: 29). Meja mrupakan salah satu perabotan rumah tangga karena meja yang dimaksud menjadi perabot rumah tangga berada di dalam rumah. Berbeda lagi jika meja yang dimaksud berkonteks di dalam sekolah. Seperti contoh yang lain pada adat Bubak 
Kawah tanda pada memakan pisang raja. Nama buah pisang raja pada prosesi memakan pisang tersebut menyimbolkan kebaikan. Kebaikan yang berarti seperti raja sehari, ratu semalam, hidupnya mulya, mulya di dunia mulya di akherat, mulya di mata manusia, mulya dihadapan Tuhannya. Berbeda dengan kebaikan pisang raja yang dipakai untuk camilan pisang goreng atau godo goreng yang biasa di jual di waraung-warung gorengan tersebut menyimbolkan kebaikan kenikmatan tersendiri bagi pecinta gorengan pisang. Perbandingan contoh tersebut menjelaskan pentingnya konteks dalam menentukan makna. Kebaikan buah pisang raja pada contoh tersebut memiliki kesamaan rasa akan tetapi memiliki arti yang berbeda pada konteks yang berbeda.

\section{SIMPULAN}

Berdasarkan hasil penelitian tanda, simbol, dan makna terdapat pada Adat Bubak Kawah di Kecamatan Gudo Kabupaten Jombang yang dilaksanakan pada tanggal 05 Desember 2019 disimpulakn sebagai berikut. Tanda yang ditemukan pada adat Bubak kawah di Kecamatan Gudo Kabupaten Jombang berjumlah 8 tanda. Tanda lebih sedikit dari pada simbol dikarenakan tanda yang berada pada prosesi adat tersebut didalamnya banyak mengandung simbol. Jadi tanda lebih didominasi oleh simbol. Simbol yang ditemukan pada Adat Bubak
Kawah di Kecamatan Gudo Kabupaten Jombang berjumlah 10 simbol.

\section{DAFTAR PUSTAKA}

Aminuddin. 2015. Semantik: Pengantar Studi Tentang Makna. Bandung: PT Refika Aditana.

Basir, Udjang Pr. M. 2010. Kajian Sosiolinguistik Budaya: "Dinamika Perkembangan Bahasa Jawa pada Pagelaran Wayang Kulit Modern dan Etos Dalang Muda dalam Budaya Jawa, Potret Cocial Culuture Masyarakat Jawa Masa Kini".

http://ikadbudi.uny.ac.id/informas i/kajian-sosiolinguistik-budayadinamika-perkembangan-bahasajawa-pada-pagelaran-wayang.

(Diakses pada tanggal 17 Februari 2020).

Basir, Udjang Pr. 2010. Menulis Artikel:

"Konsep Dasar dan Aplikasi". http://www.academi.edu/3810963 4/MenulisArtikelKonsepdasardanA plikasi. (Diakses pada tanggal 16 Februari 2020)

Berger, Peter L., Luckmann, Thimas. 2015.

The Social Construction of Reality, The Treatise In The Sociology of Reality. Garden City, N. Y.: Doubleday.

Chaer, Abdul. 2012. Linguitik Umum. Yogyakarta: Rineka Cipta. 
Jurnal DISASTRI (Pendidikan Bahasa dan Sastra Indonesia)

Volume 3, Nomor 1, April 2021| P-ISSN : 2716-4114 | E-ISSN: 2722-3329

Danesi, Marcel. 2011. Pesan, Tanda dan

Makna Teori Teks Dasar Mengenai

Semiotika dan Teori Komunikasi.

Jakarta: Jalasutra.

Pipitustari. 2015. Jenis-jenis Kebudayaan.

Blogspot.com.

Piliang, Yasraf amir. 2012. Semiotika dan

Hipersemiotika: Gaya Kode dan

Matinya Makna. Bandung:

Matahari.

Pipitustari. 2015. Jenis-jenis Kebudayaan.

Blogspot.com.

Sobur, Alexa. 2016. Semiotika Komunikasi.

Bandung: PT Remaja Rosdakarya.

Sopianah, Siti. 2013. Skripsi Analisis

Semiotika Terhadap Iklan susu

Bendera Edisi Ramadhan di Televisi.

Jakarta: UIN Hidayatullah. 